\title{
Robert Koch: „ловецът на микроби“ 175 години от рождението на учения
}

\author{
доц. Д. Паскалев \\ Медицински университет „Проф. д-р П. Стоянов“ - Варна
}

\section{Болестта и нейният причинител}

Предшествениците на туберкулозния бацил съществуват далеч преди Homo sapiens да се появи на земята. Mуcobacterium ulcerans въ3никва още в древния южен континент Гондвана, обхващал днешна Африка, Австралия, Нова Зеландия, Южна Америка и Антарктида, през периода Юра (преди 150 млн. години). Един предшественик на Mycobacterium tuberculosis се появява преди около 3 млн. години в Източна Африка и вече е бил болестотворен за живеещите тогава хоминиди. Започвайки своята миграция от древната прародина Африка преди 1.7 млн. години, първите човешки същества пренасят заболяването към Европа и Азия. А съвременните щамове на M. tuberculosis въ3никват преди 15 - 20 хиляди години. Така това смъртоносно заболяване съпътства човека още от неговата поява в далечните праисторически времена. Пьрвите цивилизации не са пощадени от туберкулозата - в мумии от древен Египет са открити костни промени от туберкулозен спондилит (Morbus Potti), датирани от преди 5000 години. Описания на туберкулозната болест се откриват в медицински текстове в древна Индия (преди 3300 години) и Китай (преди 2300 години). В Библията (Старият завет) се споме- нава за заболяването Schackepheth като болест, протичаща с тежко изтощение, а в съвременния език думата се употребява за „туберкулоза“. „Бащата на медицината““ Хипократ (460 - 377 г. пр. Хр.) познава добре заболяването, като отбелязва, че то засяга предимно млади хора между 18 - 35-годишна възраст, протича с изтощение (фтизис, охтика) на организма и завършва найчесто със смърт. Клавдий Гален $(129-199$ г. сл. Хр.) също е запознат с коварната болест и съветва лечение с чист въздух, мляко и пътувания по море.

През XIX в. смъртността в големите европейски градове Лондон, Стокхолм и Хамбург достига до $800-1000$ на 100000 души население и туберкулозата е наречена „капитан на смъртта“, т.е. водеща причина за леталитет. Причинителят на болестта обаче остава загадка и обвит в неизвестност за медицината.

\section{Предшественици}

Franciscus Silvius (1614 - 1672), чието име е епоним на sulcus lateralis cerebri (Sulcus Sylvii), прьв описва правилно туберкулите - характерния морфологичен белег на заболяването, през 1650 г. Benjamin Marten (1690 - 1752) в кратко съчинение от 1720 г. предполага за пръв път, че 
„пьрвичната, съществена и досега необяснима причина за това заболяване (охтика - бел. м.) е специфичен жив contagium vivum “. René Laënnec (1781 - 1826) обединява клиничните форми на туберкулозата (белодробни и извънбелодробни) в единно заболяване с типичен морфологичен белег туберкула. Сам жертва на заболяването, той не възприема инфекциозния характер на туберкулозата. Названието „туберкулоза“, произхождащо от туберкул, е дадено от големия немски интернист Johan Schönlein през 1839 г., a Jean-Antoine Villemin (1827 - 1892), френски военен лекар, пръв опитно доказва контагиозната природа на заболяването през 1868 г.

Датата 24.03.1882 г. е преломна в търсенето на загадъчния причинител - вечерта на този ден младият Robert Koch прави сензационното съобщение пред Дружеството по физиология в Берлин, че е успял да открие причинителя на туберкулозата. Новината обикаля Земята за 24 часа.

\section{Robert Koch (1843 - 1910) - „ловецът на микроби“}

R. Косh е роден на 11.XI.1843 г. в миньорското градче Клаустал-Зелерфелд в семейството на минния инженер Hermann Koch. Селището се намира в планината Харц, където легендите разказват, че срещу първи май на врьх Брокен вещиците си устройват сборище. Преданията и приказната природа завинаги пленяват душата на малкия Robert. През 1862 - 1866 г. младият Koch е студент по медицина в Гьотинген, където негов професор по анатомия е известният Jacob Henle; той създава революционна за времето хипотеза, че инфекциозните болести ce предават чрез микроорганизми (,contagium animatum“), невидими за момента поради несъвършенството на микроскопа. Тази идея оставя дълбока следа в ума на неговия студент.

През 1866 г. R. Koch започва работа като общопрактикуващ лекар последователно в Лангенхаген, Нимег и Раквиц, а през 1872 г. е назначен за „физикус“ (окръжен санитарен инспектор) във Волщайн (Силезия). В своя дом той устройва малка лаборатория. За неговия 28-и рожден ден неговата сыпруга му подарява микроскоп и с него младият лекар слага началото на знаменитите си изследвания. Първоначално се насочва към антракса - антропозооноза, избухнала в поверения му регион. По това време болестта нанася огромни щети на животновъдството, а някои пасбища, където животните измират масово, са наречени „прокълнати полета“. През 1876 г. R. Koch изолира и идентифицира причинителя, който нарича Bacillus anthracis, а малко по-късно описва и неговия биологичен цикъл. Това откритие трасира пътя към изработването на първата противоантраксна ваксина в лабораторията на Louis Pasteur (1881). Нейната ефикасност е демонстрирана публично от френския учен с триумфален успех. Независимо че са пионери в областта на бактериологията, между Koch и Pasteur се поражда неприязън, прераснала по-късно в непримирима вражда. Тя се подклажда от научното съперничество, амбициите за приоритет и не на последно място - от чисто шовинистични подбуди. През 1871 г. Франция търпи поражение във Френско-пруската война (1870 - 1871). В хода на войната R. Косh работи като полеви хирург в лазарет, разположен на френска територия, и проучва раневата инфекция. L. Pasteur не взема пряко участие в сраженията, но в знак на протест връща обратно своята почетна диплома от университета в Бон. През 1878 г. R. Косh публикува своите класически проучвания върху „заразните травматични болести“" и доказва шест различни вида ранева инфекция в зависимост от причинителя. В хода на изследванията той въвежда редица новости - използва анилиновите бои за оцветяване на микроорганизмите, прави първите успешни микрофотографии на патогените и оборудва микроскопа си с имерсионни лещи и светлинен кондензор, разработен от физика Ernst Abbe $(1840$ - 1905). Освен това внедрява в бактериологичната практика изкуствените хранителни среди за култивиране на микроорганизмите.

През 1880 г. е назначен за професор в Имперския здравен институт в Берлин, където през м. август 1881 г. в почти пълна тайна R. Koch се насочва към делото на своя живот - откриване на причинителя на туберкулозата. Седем месеца по-късно, на 24.03.1882 г., той докладва пред Дружеството по физиология в Берлин за своя успех. Докладът му е впечатляващ с неоспоримите си доказателства (200 микроскопски препарата), а изводът е сензационен - причинителят на туберкулозата е вече известен. Присъстващите, сред които е и R. Virchow, слушат поразени историята на едно от най-големите 
открития в медицината. През нощта телеграфите разпространяват в ефир вестта за откритието, а на другата сутрин светът узнава невероятната новина. На 10.04.1882 г. докладът на R. Koch „Die Aetiologie der Tuberculose“ („Етиология на туберкулозата“) е публикуван в Berliner klinische Wochenschrift и от него става ясно, че е открит път към точна диагноза и възможност за създаване на спасителна ваксина.

Великото откритие е последвано от колосална грешка. На 10-я международен конгрес по медицина в Берлин, пред 5000 участници от 40 страни, R. Kосh съобщава за получения от него туберкулин и че неговото инжектиране води до местна реакция. Той обаче приема, че туберкулинът, приложен повторно, има терапевтичен ефект: „,...морските свинчета, които са известни със своята възприемчивост към туберкулоза, не развиват болестта при заразяване с туберкулозни бачили, ако предварително са третирани с тази субстанция (туберкулин - бел.м.). Освен това в морските свинчета, заболели от туберкулоза, заболяването затихва, без да остави вредни последствия “.

Неговият доклад е отпечатан в извънреден брой на Deustche medizinische Wochenschrft, а пресата светкавично разпространява новината, че R. Koch е открил лечение за нелечимата болест. Настава световна еуфория и хиляди туберкулозно болни и лекари се стичат в Берлин, очаквайки да получат спасителния туберкулин. Но радостта се оказва преждевременна. Последвалите проучвания не потвърждават терапевтичния ефект на новото лекарство, a R. Virchow през 1891 г. посочва, че лечението влошава състоянието и благоприятства дисеминирането на туберкулозните бацили в организма. През същата година Koch формулира мястото на туберкулина като средство за диагноза: „С негова помош, ще могат да се разпознават неясни случаи на ранна туберкулоза“. През 1902 г. Clemens von Pirquet, виенски педиатьр, предлага своята туберкулинова проба, извършвана с борер, а през 1907 г. Charles Mantoux, френски лекар, въвежда своя тест, който носи неговото име и се провежда до днес. Така старият туберкулин на Koch, от който съществуват над 100 варианта, остава на разположение за диагностични цели и в наши дни.

Великите постижения на R. Koch, независимо от горчивото му увлечение от туберкулина, са оценени от Нобеловия комитет в Стокхолм. През 1905 г. немският учен получава Нобелова награда за медицина и физиология за своите основополагащи работи върху туберкулозата. А през 1996 г. СЗО решава да обяви 24 март, датата на която R. Koch съобщава за своето откритие, за Световен ден за борба с туберкулозата, защото болестта все още причинява смъртта на около 3 млн. души по света, а 30\% от световната популация е инфектирана с M. tuberculosis.

Годините след голямото откритие са изпълнени с многобройни пътувания в Африка и Азия, където големият учен проучва чумата по говедата, сьнната болест и маларията. През 1883 - 1884 г. R. Koch води научна експедиция в Египет за изолиране причинителя на холерата. Тогава още не е известно, че Vibrio cholerae e вече идентифициран от Filippo Pacini, италиански анатом и патолог, по време на холерна епидемия във Флоренция през 1854 г., но откритието остава непубликувано в Централната Национална библиотека на града. Косһ идентифицира причинителя и го описва с ,формата на запетая".

Големият учен приключва земния си път на 27.05.1910 г. в Баден-Баден, където умира от сърдечен инфаркт. Тялото на Robert Koch е кремирано, а урната с праха е вградена в една от стените на Института по инфекциозни болести в Берлин, който носи неговото име.

$\mathrm{R}$. Косh остава пример за поколенията със своята всеотдайност в работата, мъжество в неуспеха и скромност, независимо от постигнатото: „Работих, колкото ми позволяваха силите, и ако моят успех е по-голям от този на другите, това се дължи на обстоятелството, че при скитанията ми из полето на медицината попаднах в области, където златото още не беше прибрано, а това не е голяма заслуга“. 